\title{
Teatro y Ceremonia: algunos apuntes sobre las exequias barrocas
}

\author{
VICTORIA SOTO CABA
}

En el Dizionario delle Belle Arti del Disegno, Francesco Milizia definió la voz "catafalco" como "un mausoleo efímero para pompa fúnebre", definición clara de lo que, desde el siglo XVI, significaba tal término, pero añadía además el siguiente comentario:

\begin{abstract}
"Catafalco es una fúnebre gratitud para un difunto merecedor. Debe servir pues para un compendio de sus principales acciones expresadas con claridad, para excitar el dolor y la tristeza por su pérdida. No caprichos, ni bromas de oro, plata y de brillos, ni otras frivolidades. Unidad y simplicidad. Una pompa fúnebre no es una fiesta teatral, no admite exageraciones, jactancia y mucho menos falsedad" ".
\end{abstract}

El texto resulta de lo más significativo para comprender la trayectoria final de un género decorativo caracterizado, durante todo el barroco, por la grandilocuencia y la retórica. Ambos rasgos, presentes todavía en los aparatos escenográficos de la segunda mitad del siglo XVIII, serán el blanco de las criticas que, como la citada, reclaman un carácter más austero para las celebraciones y sus decorados.

Milizia vuelve a formular, en su obra Del Teatro, un ataque a las fantasias desbordadas de ciertos arquitectos escenógrafos de la época, pero en este caso el teớrico va más allá de calificar los escenarios efímeros de frivolezze o jattanza al escribir que éstos son producto de artistas que

“... hanno... abbandonato il fondamento dell'arte, si sono dati alla bizarria, sfoggiando fantasticamente ne'piu grande ghiribizzi, trabiccoli, centinamenti, tritumi, trafori, e in ogni sorta di stranezza..." ${ }^{2}$.

Bassano, 1797, tomo II, pág. 170.

Trattato Completo, Formale e Materiale Del Teatro, Venecia, 1794 (ed. facsimil de Forni Editore, Bologna), cap. X, pág. 70. 
Sin embargo, no son las criticas a las escenografías tardobarrocas el aspecto que nos interesa destacar en este trabajo, sino la relación entre ceremonia y teatro, dos nociones que Milizia parece definir por separado -y por primera vez- al asegurar que «una pompa fúnebre no es una fiesta teatral". La frase merece interés pues refleja una división neta entre dos palabras, "Ceremonia" y "teatro" que, durante siglos, estuvieron unidas y en el XVIII adquieren el valor de categorias autónomas al responder a fenómenos cada vez más dispares, tanto artísticos como literarios. Pero también la afirmación del teórico manifiesta que todavía, en su época, la escenografía prestaba un evidente sentido teatral a cualquier acto festivo o celebrativo. Fiesta y teatro estaban todavía en conexión a pesar de que las "actuaciones teatrales" residian ya en un marco muy preciso y no respondian al esquema de la fiesta.

Algunos trabajos intentan señalar el error de aplicar indiscriminadamente una óptica teatral, que en realidad es nuestra concepción del teatro, a acontecimientos tan diversos como son los eventos festivos de los siglos XVI y XVII ${ }^{3}$, sin embargo es indudable que existió una relación muy estrecha, una identificación que ha originado mucha historia acerca de la "teatralidad de una cultura" y en torno a los "evidentes rasgos teatrales del barroco" ${ }^{4}$. Fue, quizá, en la ceremonia de exequias, en las pompas fúnebres de príncipes, reyes y altos dignatarios donde tal identificación aparece de forma clara y explícita, donde la celebración asume datos teatrales y donde las categorias de fiesta y teatro se diluyen y se integran para convertirse en un único espectáculo, en aquella fiesta teatral repudiada por Milizia y, sobre todo, por la nueva sensibilidad que, sobre la muerte, se gesta en la segunda mitad del siglo XVill.

En el ámbito cortesano del barroco, la pompa fúnebre fue la trayectoria final de un fasto que reivindicaba la legitimidad política e histórica de! difunto, pero también la continuidad de su poder, fuera príncipe, rey o pontífice. Los funerales reales tomaron un papel de particular relevancia puesto que manifestaban visual y conceptualmente una política que había sido afirmada ya en los nacimientos y bodas, en los recibimientos o entra-

3 En el intento por delimitar dos categorias distintas, "fiesta" y "teatro", destaquemos el articulo de Ferdinando TAVIANI, "La festa recisa, o il teatro (La "Sciomachie" di Rabelais, e note)", Biblioteca Teatrale. Riviste trimestrale di studi e ricerche sullo spetaccolo, $n^{\circ} 15-16$, 1976, págs. 16-48; también el profesor Diez BorQue analiza los puntos de encuentro y las fronteras de los espacios en "Relaciones de teatro y fiesta en el Barroco Español", Teatro y Fiesta en el Barroco. España e lberoamérica, Barceiona, ed. del Serbal, 1986, págs. 11-40.

4 Entre los trabajos más conocidos cfr. Emilio Orozco, El teatro y la teatralidad del Barroco, Barcelona, 1969; Manierismo y Barroco, Madrid, 1975, asi como J.A. MARAVALL, La cultura del Barroco, Barcelona, 1975. 
das, en todos los actos solemnes o festivos, públicos o privados. Era el eslabón que abría y daba paso a un nuevo ritmo de vida y que, a través del fasto, permitía continuar la propagación de un soporte ideológico, originando unas mismas manifestaciones culturales para un mismo espectáculo, aquel que afirmaba un mismo sistema político, social y religioso. Los mensajes fueron similares tanto si se trataba de la entrada victoriosa de un rey, como de su muerte y su funeral. Todo ello era una fiesta, un instrumento de ostentación y la proyección de un poder 5 .

En España, al igual que en otros paises, un tipo de fuentes, principalmente impresas, permiten conocer las peculiaridades del gran esplendor de los funerales regios. Se trata de las denominadas Relaciones, crónicas que narran las honras y exequias celebradas por las distintas ciudades e instituciones y que describen con suma atención los aparatos y decorados ficticios. Éstos eran levantados con gran esfuerzo económico cada vez que se requeria una demostración de exequias, acto que respondia más a una pragmática soberana que a una voluntad sincera de duelo. Por regla general, las exequias se celebraban al cabo de varios meses de enterrado el monarca, tiempo que permitia un amplio desarrollo para los preparativos artísticos y los trabajos escenográficos.

El lugar del acto fúnebre, casi siempre la iglesia, debia quedar completamente transformado. Puede decirse que la escenografía como disciplina, culminará su propio objetivo artístico al transformar el interior del templo en una verdadera escena, en un auténtico teatro, término que, durante el barroco, adquiere una significación mucho más amplia que la que hoy en dia le adjudicamos. Si nos atenemos al Diccionario de Autoridades, teatro era el sitio o paraje "en que se juntaba el Pueblo a ver algún espectáculo o función", el "concurso de los que asistian" o, en sentido metafórico, "alguna cosa expuesta a la estimación o censura universal». Como señala el profesor Don Julián Gallego, al referirse al título de “Teatro" en los libros del Siglo de Oro, la palabra representaba, por extensión, "toda plataforma erigida para cualquier celebración política, litúrgica o incluso penal" 6 . En este sentido, las metáforas en torno al "gran teatro del mundo" asumen muy bien esa amplitud de significaciones con una dimensión que aúna la magnificencia de una época como escenario de una cultura?.

\footnotetext{
5 Véase el Catálogo de la Exposición Florencia y La Toscana de los Medicis en la Europa del Quinientos, El poder y el espacio. La Escena del Principe, s.a., s.l.

- Julián GAllego, Visión y simbolos en la pintura española del siglo de oro, Madrid, 1972, pág. 82.

7 Sobre este tema en particular véase el articulo de Silvia CARANDINI, "Roma, Gran Teatro del Mondo. Festa e società nel XVII secolom, Ricerche di Storia dell'Arte, n' 1-2, 1976, págs. 71 y ss.
} 
El decorado levantado en las parentaciones reales no sólo ofrece una representación iconográfica de la imagen monárquica, sino que propone una dimensión simbólica nueva y distinta para el templo. Las Relaciones sobre Honras son testigos de esa transformación. Con ampuloso estilo oratorio, metafórico y culterano, caracteristico de este género literario, la exaltación al rey se desarrolla en torno a una serie de tópicos, cuyas sutiles variaciones responden a los intereses y a los propios cambios políticos operados en la evolución histórica. La apología y la propaganda dinástica se traduce igualmente en la descripción del catafalco y de todo el decorado efímero. En algunas ocasiones, las crónicas presentan estampas grabadas de aquellos aparatos y, en menor medida, insertan planos para situar la distribución y la colocación del público. Las Relaciones, pues, son eco de la mutación operada en el interior de la iglesia al relatar además toda la trayectoria del acto fúnebre. Por un lado, las vísperas y vigilias; misas, música y coros; oraciones y sermones, todo un conjunto de gestos y actuaciones "teatrales" que la propia Iglesia asumía en su liturgia. Por otro, el protocolo y la ceremonia, al señalar el papel de los altos estamentos invitados que, por su disposición y colocación "según la etiqueta", determinaba un escenario especial para la representación fúnebre. En definitiva, toda una serie de "piezas" que desarrollaban la función dentro de un nuevo marco, efímero y provisional.

De la misma manera que sería erróno considerar la escenografía como un ente visual completamente aislado del texto de la representación dramática, es necesario plantearse la relación existente entre la decoración efímera y la literatura de las Relaciones al margen de la credibilidad que tal prosa panegírica pueda tener.

Las Relaciones son además de la clave interpretativa del aparato efimero, el texto de una representación que invita a imaginar el marco escénico de aquélla.

Si nos detenemos en los mismos encabezamientos de estos libros encontramos ya un cercano aire con la representación teatral: Llantos Imperiales de Melpomene Regia..., Teatro Augusto de el Amor y de el Dolor..., El Sol eclipsado antes de llegar a su Zenit..., España llorosa sobre la funesta Pyra..., Pantheon de el Sol, Machina Sepulchral..., Gemidos de la Lealtad, Triumphos de la Gratitud..., Minerva llorosa a impulsos de la Razón..., Llanto de la Fama..., etc. títulos que en nada están alejados con los que encabezan la producción dramática de la época y que son comunes a toda literatura laudatoria de carácter fúnebre. Hipérbole o exageración son las constantes de las descripciones de honras de la segunda mitad del siglo xVII y de la primera mitad del xVIII. Sin embargo, no es únicamente el estilo de la prosa la caracteristica que permite vislumbrar una afinidad entre los dos géneros literarios. 


\section{"...fue el lugar y Religioso Theatro en donde se celebró la solemne acción fúnebre...”}

Los autores de estas narraciones califican al templo como el teatro que ensañaba la vanitas barroca al colectivo de fieles y que avisaba que "entrando en aquel funesto teatro se contristarian, porque en él se representaba la muerte". Bialostocki ya señaló que los funerales barrocos "no fueron más que representaciones ostentosamente dinámicas y decorativas de la vanitas ${ }^{8}$, sin embargo aquellas pompas tuvieron un marco y un objetivo muy preciso: la iglesia y el público; de ahi que los cronistas utilicen todo tipo de sinónimos para expresar un mismo fin: demostración doliente, religioso y fúnebre teatro, representación, argumento... palabras que dejan clara la vertiente escénica de las exequias.

Las catedrales de las ciudades, las iglesias de las villas, la capillas de colegios e instituciones reales, los teatros de las Universidades fueron los lugares más idóneos para estos actos luctuosos. Un ejemplo, entre tantos, fue el de la corporación municipal mallorquina que, para las honras de Carlos II, no encontró "digno competente Teatro, de la Augusta Trágica Representación que esperava verse" que su catedral gótica ${ }^{9}$. En otro caso, el de la Universidad de Zaragoza, se sigue la tradición de celebar los sufragios en su propio teatro universitario, con motivo de la muerte de la primera reina difunta de la dinastia Borbón, Maria Luisa Gabriela de Saboya (1714). El autor de la Relación señala que este teatro universitario "nunca consiguió más el fin de su erección, que en esta pompa" "10, pues como años más tarde se menciona, con ocasión de las honras de Felipe $\mathrm{V}$ (1746), en él se podía upor su disposición de Tribuna, y grada, acomodar mayor concurso" ${ }^{11}$.

\section{“...supo el arte desmentir estos defectos, reduciéndolos con buen orden..."}

Los autores de las Relaciones, ampulosos y reiterativos hasta la saciedad, pormenorizaron todos los detalles de las arquitecturas levantadas en

8 Jan Bialostocki, Estilo e lconografía. Contribución a una ciencia de las artes, Barcelona, Ariel, 1973, págs. 187 y ss.

9 Real Pompa Funeral, que a las Augustas Cenizas, y Amables Memorias de el Católico Rey... D. Carlos Segundo... En el Reyno de Mallorca... de el Año 1700... En Mallorca... Año de 1701.

10 Blas Antonio de Nasarre, Funeral hecho a la Gloriosa Memoria de la Reyna... Maria Luisa Gabriela de Saboya. Por la Universidad y Estudio General de Zaragoza... En Zaragoza... Año de $1714 \ldots$ pág. 10.

${ }^{11}$ Manuel Vicente Aramburu de la Cruz. Minenva llorosa a Impulsos de la Razón, y la 
las naves y distintas partes del templo, aunque es el túmulo el elemento más considerado por sus dimensiones y espectacularidad. Antes de cualquier digresión sobre el aparato efímero, los cronistas no olvidan hacer alguna referencia al decoro artístico de la iglesia o a sus caracteristicas arquitectónicas. En este sentido, predominan las alabanzas a las excelencias del edificio. Todos los templos son suntuosos y capaces para albergar la función y la gran estructura del túmulo, como la catedral de Barcelona - "Templo sino el Mayor, uno de los más grandes y autoriçados de España. Fábrica verdaderamente Real y de pensamientos grandes....12- o la de Granada, siempre descrita en las Relaciones sobre exequias que realizaba la ciudad "para que con mayor facilidad se comprehenda el adorno instalado en ella". Asi, José Mena, cronista de las exequias de Carios II en la Real Capilla granadina, relata la historia de la fábrica -"arquitectura que el tiempo dispensa sus injurias»- para resaltar su puerta, "adornada de maravillosa arquitectura mosaica" o su magnífico retablo, "de arquitectura compuesta... del insigne Artífice Philipo de Borgoña..." ${ }^{13}$.

A pesar de las excelencias artísticas de las iglesias o catedrales, el asunto de la celebración necesitaba de otro tipo de decoro, por ello ceste día quedó oculto para no embarazar la mayor atención, no permitiendo, ni aún la luces al Sol..., vistiendo de luto la más recóndita Valdosa...." ${ }^{14}$. Las crónicas adjudican a los artífices del decorado la necesaria cubrición. El artista "desmintió sus paredes con preciosas, si bien melancólicas telas, que descendían de la cúpula a besar el enlutado pavimento". Esta era exactamente una de las finalidades de la utilización escenográfica: "desmentir" y tapar la arquitectura real.

Se plantea, pues, un problema involucrado en la "crítica" artística del momento. Dentro de la farragosa prosa de las Relaciones se manifiesta el ataque o la aceptación de los distintos estilos arquitectónicos, de manera que en esta literatura, cronológicamente muy amplia, se perfila una reflexión más del pensamiento arquitectónico del barroco. Pese a las fuertes dosis de subjetividad que entrañan estos libros, el posible debate no se

Lealtad. Reales Exequias, con que la Universidad y Estudio General de Zaragoza... lamenta la muerte de... Phelipe V... Año de 1747... En Zaragoza..., pág. 35.

12 Francisco Garrigó, Panegyrico Funeral, en las exequias de... Doña Mariana de Austria... que celebró la excelentissima ciudad de Barcelona... Con licencia en Barcelona... por Thomas Loriente Impressor.

13 Josep Mena y Medrado, Reales Exequias por la Catolica Magestad de... Don Carlos II... que dedica la Muy Noble, muy Nombrada, muy Leal y Gran Ciudad de Granada... en los dias tres y cuatro de Diziembre de 1700.

14 Oficios Funerales, con que dio señas de sentimiento en la muerte de la Reyna... Maria Luisa de Orleans, La Venerable Orden Tercera de Penitencia... en esta Imperial y Coronada Villa de Madrid... Con licencia. En Madrid: Por Juan Garcia Infanzón, pág. 7. 
dirige tanto a lo efímero, fruto de los cánones artísticos del momento, como a la alabanza o a la critica que se establece en los distintos comentarios del edificio o de las iglesias elegidas para la función.

No siempre el interior del templo era "desmentido" con lutos y tapices. Muchas veces se dejaba al descubierto ciertas partes, retablos, capillas etc... Es significativo lo que nos dice la Relación de las exequias de Fernando VI a instancias de la Hermandad del Refugio en Madrid, el año de 1760. El lugar fue la iglesia de San Antonio de los Alemanes y quedó toda cubierta de bayetas y colgaduras: el atrio, el pórtico y el pavimento. Se levantaron tribunas para los músicos e invitados, pero "dessando essenta la magnífica Pintura del Templo, que por tan preciosa, no pareció correspondiente cubrirla» ${ }^{15}$.

Si bien casi siempre son loas a la iglesia elegida, en algunas crónicas encontramos una sincera crítica arquitectónica. Es muy revelador seguir la trayectoria a la iglesia de Santiago de los Españoles, donde la embajada y súbditos celebraban exequias por todos los monarcas hispanos. En este caso, la Relaciones indican las pequeñas dimensiones de la iglesia, un aspecto que los cronistas señalaban para estimar, por un fenómeno de contraposición, la magnitud de proporciones del adorno efímero. Así esta iglesia no contaba con una disposición clara, "es pequeña, y no tanto por la estrechez del sitio, quanto por la disposición de su fábrica que da poca comodidad" para levantar el túmulo ${ }^{16}$. Se trataba de una iglesia gótica cuya fachada principal daba a la Sapienzia y la otra a la plaza Navonna. Si partimos de la descripción que Pérez de Rúa realizó en el libro de honras de Felipe IV (1666), momento de máximo desarrollo artístico barroco, la iglesia de Santiago es considerada como "arquitectura antigua y desproporcionada". No obstante, el cronista salva añadidos posteriores de ciertas capillas "de bien ordenada fábrica y de excelentes mármoles" ${ }^{17}$. No serán tan benévolos los sucesivos comentarios. En 1724 y 1746, honras de Luis I y Felipe V, coincidiendo con las realizaciones del barroco clasicista, la iglesia responde al "tosco orden gótico" y "aunque es de piedra no tiene hermosura alguna» ${ }^{18}$; más duras fueron las frases impresas en el libro de exequias de Carlos III (1789): "templo por su construcción el más

${ }^{15}$ Relación de las Magnificas Exequias que celebró por el rey... Don Fernando Sexto... La Santa Hermandad del Refugio y Piedad de esta corte... En Madrid... Año de 1760, sin paginar.

${ }^{16}$ Antonio Pérez de Rúa, Funeral hecho en Roma en la Yglesia de Santiago de los Españoles a 18. de Diciembre de 1665... A la gloriosa Memoria... de D. Felipe Quarto el Grande... En Roma, pág. 35.

17 Ibidem, pág. 31.

18 Relación de las Reales exequias hechas en Roma a la Magestad Católica del Rey N.S. Don Phelipe V... En Roma... MDCCXLVI. 
desacomodacio, feo y quasi bárbaro. No es de ningún orden de Arquitectura: ningún miembro corresponde a otro: no se descubre en él la menor proporción arquitectónica... ${ }^{19}$. En una época en que los resultados de las ideas neoclásicas han quedado plasmados en la producción arquitectónica de toda Europa, habria que pensar que el ataque no iba dirigido tanto al estilo "tosco" del gótico como a la mala representación que la "Nación Española" tenía en Roma.

Para evitar una imagen pobre en una demostración, cuya intención era tributar honores póstumos al difunto a la vez que adular al más alto estamento de la pirámide social, la escenografía prestaba su auténtica circunstancia "provisional y transitoria" que, en pocos dias, transformaba las superficies de la iglesia en "un nuevo, hermoso y magnífico templo". No hay pudor alguno en estas fuentes a la hora de declarar la verdadera condición "imitativa" de los trabajos realizados: "siendo las pilastras de la iglesia... de forma gótica, para cubrir su rústica y antigua estructura se hicieron otras tantas pilastras de madera, que las hermoseaban ${ }^{20}$. Condición que jamás desmerecía con respecto a la realidad y que podía engañar al espectador sobre la verdadera naturaleza de sus materiales, equívoco que se convierte en tópico de la crónica, como el siguiente comentario acerca del aparato fúnebre en la catedral de Toledo por Luis I (1724): “Se esmeró en su dibujo tan valiente, y tan equivocado, que era difícil distinguir a la vista quales eran los que abultava el lienço, ò quales los que pintó la tabla»"21.

Pintura, tapices y toda clase de ornamentos suntuarios intervienen para favorecer el equívoco: mármoles y jaspes, oro y plata brillaban en los armazones hechos de madera, en los lienzos, en los estucos y modelos de pasta. De madera se erigía el túmulo, se cubrian pilares y se tapaban «imperfecciones». La pintura se ocupaba de mutar este material deleznable por otro aparentemente unoble y magnifico": daba vida a las figuras corpóreas del túmulo, a las grandes acciones del difunto en las telas y lienzos que de aquél colgaban, declinándose para hacer coherente el programa iconográfico con toda una literatura adjunta, emblemas, empresas y jeroglificos principalmente, dispersados por todo el ámbito del templo ${ }^{22}$.

19 Relación de las exequias que celebraron los Españoles en su Yglesia de Santiago en Roma a la Memoria del Rey Carlos III.. En Roma, MDCCLXXXIX, pág. V.

${ }^{20}$ Relación de las Exequias que a la Magestad del Rey Católico D. Fernando V/ se hicieron en la Real Yglesia de Santiago de los Españoles en Roma... Con licencia en Roma, MDCCLX, pág. XXXI.

21 Pantheon de el Sol, Machina Sepulchral. Demostración Luctuosa que la Imperial Toledo Executó Llorosa, construyó Liberal y órreció Amante a las Memorias, sepultadas nunca de el Joven Príncipe Nuestro Señor, y rey Don Luis Fernando... En Toledo. Año de 1724...

${ }^{22}$ Sobre esta producción, véase el citado libro de Julián GÁLLEGo. 
Grandes tapices escondían muros, puertas y ventanas, un dosel flotante, generalmente bajo la cúpula del crucero, coronaba el fúnebre mausoleo, y bayetas y alfombras tapizaban todo el pavimento; de la misma manera se enlutaban tribunas y bancos - «fue preciso vestirla de luto, para que luciese más»- para que no se advirtiera ni un resquicio de luz. Ésta quedaba bien distribuida a base de hachas, velas y bujias que tenuemente, sobre candelabros y cornucopias, resaltaban las partes que más interesaban, los dorados de las cornisas, los verdes, azules y morados de estas "envolturas" arquitectónicas, las banderas, armiños y gasas que pendian de los tapices, etc.... Pero la acumulación de luz, a base de cera, se centraba en torno al túmulo con el fin de que quedara perfectamente visible a los espectadores. La transformación en algunos casos afectaba al pórtico y fachada del edificio y, como si de un cartel anunciador se tratara, su decoración invitaba al público "a ver lo que havía de nuevo en la Yglesia" y "que advirtiesse con dignidad a los que pasaban por la calle la augusta función que se celebraba dentro".

\section{“...confundían con la diversión a la congoja..."}

La novedad era la causa de esta espectación que hacía de la iglesia un verdadero lugar escénico. El cambio radical de la arquitectura, su contenido iconográfico junto con la exposición de adornos suntuosos -cetro y corona en el túmulo, como insignias de la majestad; telas ricas y bordadas; en los altares joyas, cruces de materiales nobles y piedras preciosas... -declaraban el momento de máximo esplendor del templo. El decorado convertía la iglesia en "un compuesto de bien ordenadas obscuridades, y resplandores, que entristeciendo agradaban, y agradando entristecian» ${ }^{23}$.

La insistencia en tratar de conjugar las dos impresiones - rjuntanto lo triste con lo magnifico»- hay que ponerla en relación con la importancia que adquieren los sentidos, sobre todo la vista, en las manifestaciones culturales del Barroco: «hizo a los ojos tan agradable la tristeza...", "solamente la vista podia gozar de sus perfecciones...".

Por otro lado, la oscuridad de las naves de la iglesia por las bayetas, tapices y doseles - "la obscuridad de los lutos y clausura de las ventanas, sin más luz que la que dan dos Achones"- daba pie a que los autores exageraran aún más las identificaciones con el templo: "un pavoroso y

23 Juan Gaspar DE CAÑAS y Truxillo, Exequias en Roma a la Magestad Católica del Rey Nuestro Señor D. Luis Primero... En Roma... MDCCXXV, pág. XIX. 
triste tribunal", "una negra noche de dolor...", "un lucimiento melancólico..." La alternancia en la utilización del oro y del negro engañaba, "confundian con la diversión a la congoja". Pero este equivoco, que es otra cualidad inherente de la escenografia de las arquitecturas efimeras, era un juego necesario para unir los polos opuestos, lo "melancólico" del motivo con lo "agradable" del arte: "para que lo melancólico y triste del aparato no atemorizase, avía también lo festivo y alegre con tan peregrino enlace, que embelesaba al mirarle ${ }^{24}$.

Agrado y tristeza eran dos sensaciones que el cronista debía de justificar, pues el costoso decorado estaba motivado por un sentimiento exigido de aflicción, suceso que debia celebrarse con la máxima pompa y magnificencia.

La conjunción de conceptos dispares tiene un reflejo paralelo en la propia "lección" iconográfica que propagaban las funciones fúnebres. No hay que olvidar que la misma distribución de ornamentos macabros, esqueletos en el túmulo y tibias y calaveras por todo el entorno de los muros, se articulaba con estatuas de las Virtudes, mensajes paradigmáticos pertenecientes al género emblemático, exaltadas inscripciones al monarca y a sus hechos históricos. La vanitas barroca era la representación de dos polos opuestos: la vida y la muerte, como también lo fueron estas funciones, la exaltación de la vida de un monarca ya difunto ${ }^{25}$.

Si los mismos cronistas son conscientes del fenómeno de la integración de las artes -definido muy bien por el profesor D. Antonio Bonet como "summas visuales" " denominadas artes "liberales" y "mecánicas", no olvidan reflejar la tan mencionada literatura emblemática, fundamental pasaje para la compren-

24 En Relación de las Reales Exequias hechas en Roma a la Magestad Católica del Rey N.S. Don Phelipe V... op. cit.

25 Bialostocki comenta la diferenciación de los tres grupos de simbolos que estableció Bergström en su trabajo sobre la naturaleza muerta, simbolos que tienen una perfecta correspondencia con los que hallamos en las descripciones de las pompas fúnebres: simbolos de la mortalidad humana (esencialmente la representación del esqueleto, del reloj de arena, etc...); simbolos de la resurrección de la vida eterna (quedan inscritos en el programa con una serie de yuxtaposiciones religiosas y mitológicas y con carácter alegórico) y, por último, los simbolos de la existencia terrenal. Estos son divididos en tres tipos: la vita contemplativa al que pertenecen la literatura, las ciencias y las artes (es decir, el aparato escenográfico), la vita practica o las joyas que aluden a la riqueza y al poder (las denominadas cinsignias de la majestad": cetro, corona y espada) y la vita voluptuaria o toda clase de objetos relacionados con los placeres sensuales (en donde sólo nos arriesgamos a incluir la música y coros, incluidos en el ceremonial litúrgico), cfr. Jan BialostOCKi, op. cit., pág. 198.

${ }^{26} \mathrm{cfr}$. Antonio BONET CORREA, "La fiesta barroca como práctica del poder", Diwan, $n^{\circ} 5 / 6$, Zaragoza, septiembre, 1979, págs. 53-85. Ver además, del mismo autor, “Arquitecturas efímeras. Ornatos y Máscaras" en Teatro y Fiesta en el Barroco, op. cit., págs. 41-70. 
sión del contenido de este escenario y cuya importancia estaba bien patente al quedar impresa casi siempre en los libros estudiados ${ }^{27}$. El carácter teatral estaba también originado por esa unión entre la representación "muda y congelada" de las figuras y del "rasgo de los pinceles" y los mensajes proclamados en las poesías, lemas e inscripciones.

\section{"...Llenaron de tanta Magestad aquel Teatro, que pareció se transmu- taba de Funeral en obstentoso Teatro de la Grandeza y Gloria del Difunto..."}

"Está muy lejos del deber a los muertos el ser modestos con ellos..." escribió el padre Menestrier en su Tratado Des Decorations Funebres al referirse a las honras de los grandes príncipes ${ }^{28}$. La frase cuajó como un dogma y fue proclamada de muy diversas formas por los panegiristas. Para Juan de Vera Tassis, autor de una de las Relaciones más afortunadas del siglo XVII, las pompas fúnebres quedaban justificadas por la «venerable Antigüedad, pues aún en la muerte han de tener distinción los Príncipes y Varones llustres, que supieron en vida coronarse de virtudes, proezas y méritos " ${ }^{29}$. Las justificaciones se acompañan con reiterativas citas en torno a los mausoleos y monumentos que en la Antigüedad se levantaron por los grandes héroes, citas obligadas en todos los libros sobre honras. "A la gloriosa posteridad de los difuntos" se levantaron las pirámides, los mausoleos griegos y los arcos romanos. Se recurre a los clásicos y a la Biblia, no sólo como autorización histórica de la pompa sino para calificar al túmulo de "Mausoleo de Artemisa" o de "Templo de Salomón".

No hay que olvidar que la representación aclamaba a un soberano difunto que entraba en un nuevo reino; el túmulo es calificado con apelativos de "trono", pues "se daba asiento a la Magestad difunta", "regio Alcázar", "Panteón del Cielo" etc... Se trataba también del último triunfo del difunto; como señala una de las crónicas sobre las exequias de María Luisa de Borbón en la Encarnación, la ceremonia de despedida debia ser tan magnificente como la del recibimiento: “a la entrada Triunfal en la Cor-

\footnotetext{
27 La literatura de empresas y emblemas entra dentro de lo que Maravall denominó "la idea de lo inacabado", característica de las producciones culturales del barroco en las que se requiere al espectador un esfuerzo por colaborar y descifrar el mensaje; véase "La literatura de emblemas en el contexto de la sociedad barroca" en Teatro y literatura en la sociedad barroca, Madrid, 1972.

${ }^{28}$ P.C.F. Menestrier, Des Decorations Funebres, Paris, MDCCLXXXII, pág. 38.

29 Juan dE VERA TASSIS Y VILLARRoel, Noticias Historiales de la enfermedad, muerte y exequias de la esclarecida Reyna de España Doña Maria Luisa de Orieans... En Madrid... Año de 1690, pág. 131.
} 
te, que tan grande fue, y tanto en la demostración a las naciones, y si como se executó aquella grandeza, y obstentación, es debido obsequio, y última demostración, que no executada, fuera muy reparable Triunfo a los Vivos y Triunfo a los Muertos" ${ }^{30}$. De igual manera, la narración de las exequias por Luis I en Toledo recuerda la estancia del joven rey en la ciudad y el recibimiento que se le tributó, mencionando las escenografias erigidas en las calles para contrastar con el túmulo y decorado del templo «que lo representaba difunto" ${ }^{31}$. Un siglo después, con motivo de las honras de Carlos III, uno de los cronistas continua la misma disertación barroca: «en la muerte nace su triunfo, les tributamos honra en la sepultura para significar que desde los sepulcros da principio la manifestación de su gloria” ${ }^{32}$.

Frases muy comunes relacionadas con la complejidad iconográfica del túmulo son referidas en numerosas ocasiones como una muestra permanente del valor dado a la imagen, ya que "aún cuando no se entienden, recrean y admiran a la vista, aplaudiendo los ojos lo mismo que no percibe el entendimiento...» a diferencia de otros "Artefactos mecánicos... sino se entienden, causan hastio y ni se admiran ni aún se miran..."33.

En 1700 el túmulo que se levantó en la ciudad de Barcelona por el último Habsburgo "representaba a Carlos muerto, le aclamava la Poesía glorificado e inmortal: tanto es el poder del poético Numen...»" ${ }^{34}$. Comentarios acerca del postrero culto al monarca se justifica con el discurso tópico de las virtudes obradas en vida por el difunto. Se levantaba asi uun túmulo que podía equivocarse con el templo... templo de Cathólica Virtud» ${ }^{35}$. EI resto del decorado también es motivo de alusiones relacionadas y comparativas con el túmulo, pues éste es considerado como la «idea" primordial. La representación escénica abarcaba todo el templo y aunque «la idea del Túmulo, no fue más que hazer un solo Hieroglifico, constante de muchos, engazados en dependida continuidad con el todo: Este representaba la

30 Juan Manuel de LA PARRA, Exequias Reales, celebradas en el Real Convento de la Encarnación de esta Corte. Origen de los túmulos que se hallan en las Sagradas Letras... Año de 1689, pág. 3.

31 En la Relación citada de Pantheón de el Sol, Machina Sepulchral.

32 Pedro Garcia Diego, Finezas de el Dolor, Veneración y Fidelidad, Demostradas en la Relación de las Solemnisimas Honras, que la M.N.S. Leal Ciudad de Santander consagró a... el Señor Rey D. Cartos III, sin paginar.

${ }_{33}$ Miguel MonReAL, Teatro Augusto de el Amor, y de el Dolor, en las Reales Exequias; que celebró a el Rey Nuestro Señor Don Carlos Segundo... la siempre augusta Ciudad de Zaragoza... En Zaragoza... Año de 1701, pág. 295.

34 Josep ROCABERTI, Lágrimas Amantes de la Excelentissima Ciudad de Barcelona con que agradecida... Demuestra Su Amor... a las memorias de... Carlos II... Barcelona... Año de 1701 , pág. 94.

35 Ibidem, pág. 76. 
Vida, la Muerte, el Sepulcro y la piadosamente creida salvación de la Reyna... los demás pensamientos acompañaban al principal...»36.

Para los autores que escribieron las Relaciones, la representación tenia siempre una intención claramente aleccionadora, exponer las «prendas de nuestro Difunto Rey... que acordasen a los vivos sus exemplos" ${ }^{37}$. En una fecha tan tardia como 1789, las exequias por Carlos III en algunas ciudades arrastran todavía este resorte barroco: “... no hubo cosa en el túmulo, que mudamente no predicara moralidades... la idea, el aparato, la pintura, todo figuraba a la muerte, todo era una patética exortación que avisaba a quantos lo miraban... era una Escuela, donde sin voces se enseñaban verdades y se reprochaban vicios....38.

\section{"...se dexaba ver de todos los que concurrieron en el Teatro..."}

Junto a esta visión de las Relaciones, puramente literaria y metafórica, hay otra serie de aspectos que nos indican el evidente carácter teatral del templo. En primer lugar, la distribución y disposición que adquiere la iglesia para la celebración fúnebre. En ella el túmulo o catafalco se convierte en punto referencial. Colocado, por regla general, en el medio del crucero, bajo la cúpula, focalizaba completamente la función litúrgica. La estructura efímera pasa a ser el escenario sacro que en otras representaciones es patrimonio exclusivo del altar mayor, dado que en su interior se instalaba un altar o varios para la celebración de la misa, algo que no sólo señalan las Relaciones sino que fueron normas estipuladas por la etiqueta palatina cuando las exequias se realizaban en Madrid y las sufragaba la Corte: "Dentro del túmulo, en las quatro esquinas se ponen asientos para los obispos que dizen los responsos y para los diáconos que los asișten..." ${ }^{39}$.

\footnotetext{
36 Jorge DE PINTO, Llantos Imperiales de Melpomene Regia. Llora la muerte de la Inclita Reyna y Señora Doña María Ana de Austria, madre de Don Carlos II... En Madrid...

${ }_{37}$ Descripción de las Exequias, que el Real Colegio de San Phelipe, y de Santiago de la Universidad de Alcalá... celebró por Fernando VI... Madrid... MDCCLXI.

${ }^{38}$ En la Relación citada de Pedro Garcia Diego, sin paginar.

${ }^{39}$ Ceremonial para la celebración de Honras en sufragio en Señores Reyes, Reinas, Príncipes jurados y Soberanos y principes extranjeros, 1711. Archivo General de Palacio (A.G.P.), Sección Histórica, caja 78, leg. 8. Dentro de la invariabilidad de la etiqueta a lo largo de los siglos XVII y XVIII en cuestión de honras fúnebres, hemos elegido este manuscrito de 1711 por dos razones. Más de once copias manifiestan que fue seguido hasta la cuarta década del siglo XVIII (de 1746 es la última copia, fecha de las exequias de Felipe V) y normalizó las ceremonias de la segunda mitad. Los expedientes señalan que fue copiado del ceremonial de los últimos Habsburgo al tener que celebrarse las primeras grandes honras por los Borbones en Madrid: las del Delfín, hijo de Luis XIV y padre de Felipe V, fallecido en 1711.
} 
La integración del personal eclesiástico en el catafalco implica unas nuevas connotaciones con el entramado ritual de la ceremonia. El túmulo tapaba la zona de la capilla mayor para proyectar al centro del crucero el fundamento esencial de la función y ser asi el foco de atención y punto de mira desde todas las zonas de la iglesia, donde la distribución de los asistentes contará también con una repartición estricta y marcada por la regulación cortesana.

Las etiquetas palatinas ofrecen las normas ornamentales de la celebración y coinciden con los planos conservados que marcan la transformación y la distribución realizadas en las honras madrileñas de finales del siglo XVII y comienzos del XVIII, en las iglesias de la Encarnación y de San Jerónimo el Real ${ }^{40}$. Para empezar, las etiquetas señalaban la supresión de elementos que pudieran interferir la colocación del túmulo: "Quitese la Rexa de la Capilla Mayor para dar lugar..." ya que cualquier paramento que limitara la zona del altar mayor carecía de sentido. Ante los gráficos se puede observar que esta zona se prolonga hacia el catafalco, pues éste se ha elevado al mismo nivel de altura, fenómeno corriente en los túmulos, casi siempre erigidos sobre una alta plataforma o sucesión de zócalos o tarimas.

Por otra parte, las normas no olvidan la decorosa cubrición de las paredes de la iglesia: "Cuélguese de la Capilla Mayor telas de oro, damascos y terciopelos... Cuerpo de la iglesia, suelos y bancos hasta la puerta de paño negro...". La calidad de las "colgaduras" iba paralela a la jerarquización de las distintas partes del templo. Tal jerarquización era mantenida en la distribución de los concurrentes. Mientras que la desplazada capilla mayor era la zona reservada al clero oficiante, las capillas del crucero se convertian en tribunas espectadoras más cercanas al túmulo; la del Evangelio para el Rey y su familia, en el caso de que asistieran, Grandes de España y criados de la Casa Real, y la de la Epistola para embajadores, prelados y capellanes de honor.

\footnotetext{
40 Dos dibujos de los planos de la iglesia de la Encarnación y de San Jerónimo con los "lugares en función de Honras", $n^{\circ} 2.661$ y $n^{\circ} 2.662$, A.G.P., Sección Planos. Firmados por Teodoro Ardemans, uno de ellos con fecha de 1712. Ardemans fue el encargado del túmulo y de la decoración de las exequias que por el Delfin de Francia se celebraron en el Convento de la Encarnación en 1711. En realidad, no hace más que aplicar la misma distribución presentada en el grabado del plano de la relación impresa que se hizo por las honras de Maria Luisa de Borbón en 1689 en la misma iglesia, que a su vez coincide con el plano impreso del libro de las honras por Felipe IV en el mismo convento, el año de 1666. Ardemans fue también el artífice de la decoración que un año más tarde se levantó por el segundo Delfin y su esposa en la íglesia del convento de San Jerónimo, siguiendo idéntico esquema al utilizado en la Iglesia de la Encarnación.
} 
La radical transformación de funciones no sólo afectaba al crucero, sino también a la nave central. Tal y como puede observarse por los gráficos la ceremonia discurre en una zona bien delimitada. Según las etiquetas se estipulaba un sitio específico y acotado para la clase política, puesto que en caso de "reales exequias" en Madrid todo el cuerpo del Estado estaba obligado a asistir. En tal caso, la nave central era recorrida paralelamente por unas vallas longitudinales que conformaban las tribunas de los diferentes miembros de los Consejos ${ }^{41}$.

Es decir, la distribución de gran parte de los invitados quedaba totalmente limitada mediante un cerco de madera, levantado en el sentido longitudinal de la iglesia y marcando, por tanto, una dirección única hacia el túmulo. Esta zona ocupaba, pues, toda la gran nave de la iglesia hasta el limite con el crucero. En algunos gráficos se indica que la altura de las vallas era de cuatro pies, una altura que restringía aün más ese lugar de la ceremonia estrictamente político, a la vez que servia de obstáculo físico ante la entrada y presencia del pueblo y curiosos. Las vallas servian también para encuadrar un amplio pasillo a lo largo de la nave, cuya finalida está también relacionada con el sentido procesional del acto. Los miembros de los distintos Consejos entrarian en solemne procesión para sentarse a los márgenes interiores de todo el vallado, en doble hilera de bancos. Las vallas, decorosasamente enlutadas acotaba la posible dispersión visual, ayudadas por la cubrición de tapices y bayetas negras en las naves, capillas laterales, muros, columnas o pilastras, dirigiendo las miradas hacia la fúnebre máquina que, aún en su lejania, se levantaba a una altura prodigiosa ante los más alejados del núcleo de la ceremonia. Toda la atención la reclamaba "el espacioso Teatro del Crucero".

Al igual que en Madrid, en el resto de las ciudades se producía una centralización semejante en torno al lugar donde se levantaba el túmulo, bien en el crucero, en una capilla lateral o en el medio de la nave central. En muchas iglesias y catedrales el coro y las rejas impedian una perfecta instalación del catafalco, pero fuera cual fuera el lugar escogido la más exacta etiqueta se ocupaba de ordenar «los assientos del Real Acuerdo, Santa Inquisición y Ciudad". Asi, todos los cronistas de las exequias granadinas nos relatan la disposición de tablados "a un lado y a otro de las Rejas del Crucero... el de la mano derecha para el Real Acuerdo, y sus Ministros, y para el Santo Tribunal de la Inquisición: y el de la mano

41 “El cuerpo de la Yglesia de la rexa â fuera está zerrado con vallas desviadas de la puerta principal veinte pies y de las paredes tres pies y las puertas de estas vallas tienen los porteros de Camara y dentro de ellas se ponen los vancos para los Consejos en que se sienten por sus procedencias..." Ceremonial para la celebración de honras..., A.G.P., Sec. Hist., caja 78 , leg. 8 . 
izquierda para el cabildo de la Ciudad, y su corregidor, y uno y otro enteramente vallado, y con la disposición de lugares, preeminencias, alfombrados, bayetas y demás circunstancias, que para Tribunales del tal representación, y en tal día, pide la ocasión, y dispone la costumbre...." ${ }^{42}$.

Si la nueva disposición del templo con sus bancos y tribunas se revela como una de las partes principales del marco escénico -la de los espectadores- hay que seguir las imaginativas frases de los textos panegíricos para no dudar del carácter teatral presentado en el aparato decorativo, esencialmente en el túmulo-altar de los oficios fúnebres, es decir, la escena.

La estructura central que formaba parte del programa diseñado para la exaltación monárquica, se presenta, como ya se ha dicho, parangonada con otras figuras por parte de los ampulosos autores. La que más cabe destacar va a ser la que identifique el túmulo con un templo, por dos razones; porque en su altar evolucionaban los actos religiosos y en segundo lugar, porque asi se resalta precisamente la idiosincrasia divina de la monarquía, que "por su santidad... pudo parecer más digna de obsequios que de obsequias, más benemérita de cultos que de llantos ${ }^{43}$.

El túmulo iluminaba la oscuridad del acto y del templo. Su luz era pretexto para todo tipo de metáforas: Volcán, Etna y Vesubio, Ocaso del Sol, Pyra de Afectos, Babel de Antorchas, Pyrámide de Resplandor... otros sinónimos utilizados para identificar la falsa construcción del catafalco. Entre ellos será el "Sol" la imagen literaria preferida para las digresiones laudatorias en torno al difunto. Las luces del túmulo iluminaban la oscuridad del templo como los rayos solares to hacian en el orbe hispano, al igual que el soberano que con su virtuoso ejemplo iluminaba los corazones de sus vasallos. Durante las últimas décadas del siglo xvil la representación del rey-sol en la iconografía se encontraba ya muy establecida y será en muchos casos la base argumental de este tipo de celebraciones. Daba lugar a que se inflara de un contenido claramente cosmográfico: cielo, estrellas, eclipse se suman a la terminologia fúnebre. Numerosos son los ejemplos que comparan las luces con las estrellas, el templo con la noche, la bóveda con el cielo, las lámparas con la luna, los inciensos con el ara y, por último, el túmulo con un sol eclipsado, con el empíreo o con cualquiera de las figuras citadas.

42 Sacrificio a Dios Inmortal, Regia Parentación y Magestuosas Exequias, que.. consagra... a El Primero Luis Rey de las Españas... que celebró... la Santa Iglesia Cathedral, Metropolitana, y Apostólica de Granada, en cuyo nombre se consagra esta Descripción al Rey N.S., pág. 14.

43 Miguel Monreal, Imperiales Exequias, que en la muerte de la Señora... Doña Mariaria de Austria celebró la Imperial Ciudad de Zaragoza... Año 1696. 
Es evidente la importancia concedida a estas estructuras por la detallada descripción que los autores dan de ellas, su insistencia sobre su altura y medidas, en varas o pies, hacian que se distinguieran por su elevación, sin olvidar las exageraciones propias del texto, y se caracterizaran en reducir el ámbito del templo dejándole "comprimido al efecto de abrazar la Regia Joya, que ilustraba su centro".

Si la efímera transformación de la iglesia y las alusiones de los textos nos hablan de la espectación y la teatralidad que producian las ceremonias fúnebres, hay que tener en cuenta, sin embargo, un último aspecto fundamental para entender lo que el profesor D. Emilio Orozco denominó como "el general sentido de teatralización del templo" ${ }^{44}$. Se refiere al efecto escénico y a la dirección psicológica que provocaban en el público los interminables y copiosos discursos lanzados por el orador de turno. Desde el púlpito -normalmente situado en una de las paredes de la nave central más próxima al crucero, convirtiéndose en un elemento más de la centralización de este teatro- la elocuencia y la oratoria invitaban a que se meditara sobre la propia muerte y lo que alli se representaba ${ }^{45}$; “... esos tristes objetos que tenemos a la vista, esos velos de la muerte, ese lúgubre canto, esos blandones fúnebres, todo este aparato de luto y tristeza, que inspira al alma un secreto horror, ¿no nos acuerda bastante nuestra propia nada?..." ${ }^{46}$.

El monólogo, oración o sermón, integrado en los libros sobre honras, explica muchas veces el argumento iconográfico de las instalaciones ficticias para transmitir las loas al soberano. La representación escénica dejaba de ser muda. El orador planteaba una lectura más a los maravillados concurrentes del espectáculo, en términos muy semejantes a los parangones mencionados.

La masa popular tomaba un papel importante en la ceremonia, siempre deseosa de ver la novedad introducida en la iglesia. El gentío iletrado no era ajeno a las imágenes tan difundidas de la cultura barroca y sus celebraciones, como tampoco lo era de las transformaciones que desde

\footnotetext{
${ }^{44}$ Emilio Orozco, "Sobre la teatralización del templo y la función religiosa en el Barroco: el predicador y el comediante. (Notas de una introducción al Barroco)", Cuadernos para la Investigación de la Literatura Hispánica, Madrid, F.U.E., n² 2-3, 1980, págs. 171-188.

45 Vovelle resalta el papel jugado por Bossuet en las honras francesas del Grand Siécle. como el contrapunto literario de las tumbas y monumentos funerarios y como pieza esencial del ceremonial que convertia el acto público en un "verdadero ejercicio de simulacion", cfr. Michel VOVELLE, Mourir autrefois. Attitudes collectives devant la mort au XVII et XVIII siecle, Paris. Gallimard, 1974, pág. 67.

${ }_{46}$ Oración Fúnebre de los Señores Fernando Vl y Maria de Portugal, Rey y Reyna de España... En Madrid... Año de 1760, pág. 2.
} 
un punto de vista formal ofrecia el templo. Sin embargo, se ha dicho que las exequias eran motivo para dar el máximo esplendor al templo y que los elementos nobles y suntuarios (incluidos en ellos las joyas, cruces, blandones de plata, costosas telas, etc.) acompañaban para realzar el decorado. Era este lujo la más afín similitud del poder y la mayor indentificación con la grandeza -no olvidemos que la principal riqueza del pasado barroco estaba constituida, según lo demuestran los inventarios de palacio, por los tapices, alfombras y telas... después, claro está, de los lienzos y pinturas-, y el que provocaba la admiración del pueblo al que se le permitia entrar a la iglesia "para la expectación común" y "para que se satisfaciese la curiosidad de muchos".

Junto con el lujo y el gusto por lo macabro, el pueblo era el mejor receptor de la representación fúnebre al aceptar esa tercera dimensión imaginaria de la escenografia y al confundir, como "aseguran" los cronistas, la realidad con la ilusoria transformación simbólica y formal del templo.

Los textos y las crónicas de las Relaciones reflejan que, durante el barroco, la ceremonia fúnebre fue más que nada una fiesta teatrai. Su carácter festivo y escénico se mantuvo en tanto en cuanto la escenografía cumplió su cometido teatral, transformando la forma y función de las distintas partes de la iglesia en un marco espacial, literario e irreal. 


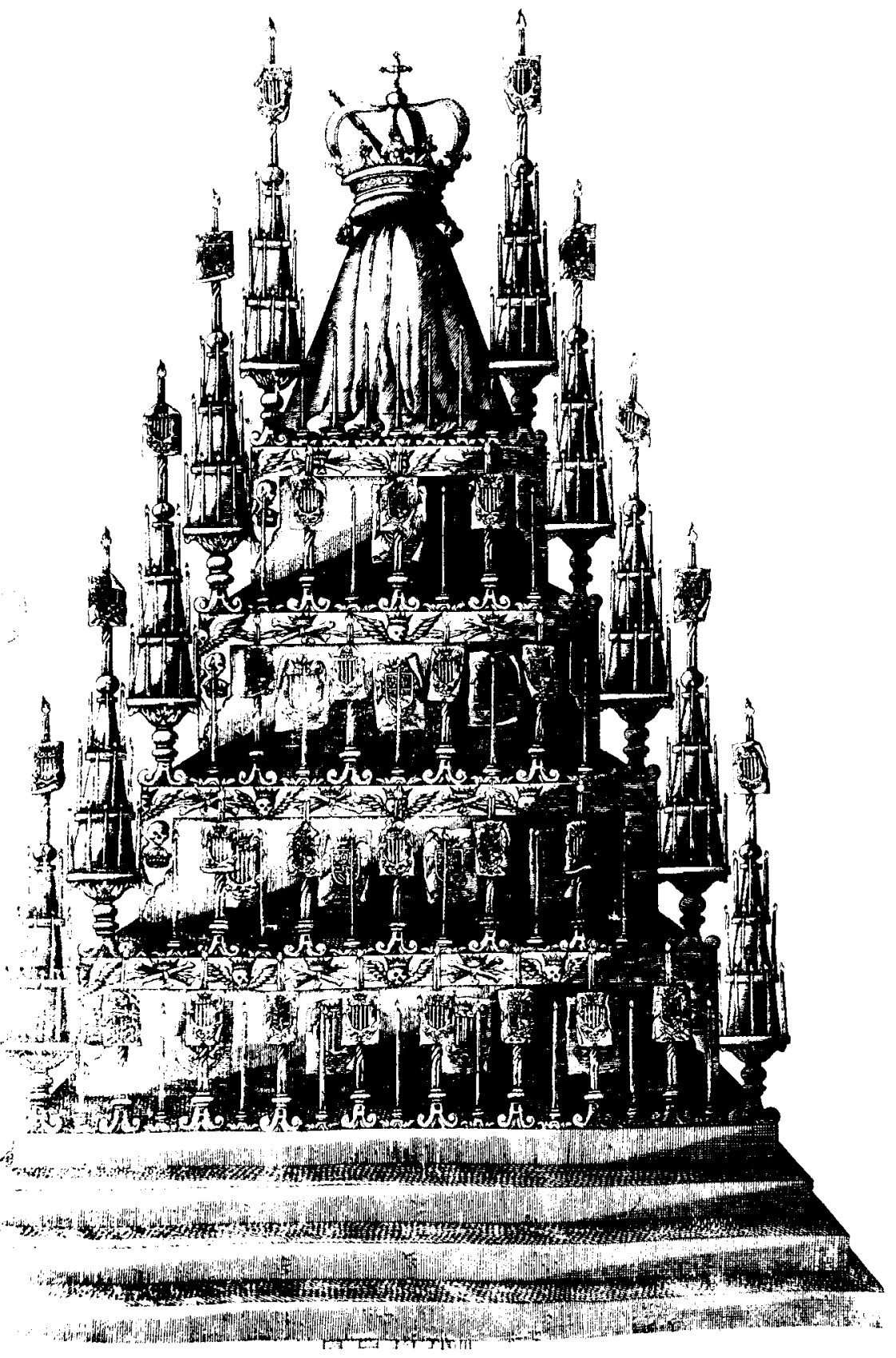

Fig. 1. Túmulo levantado para las honras de Carlos II en Mallorca, Año de 1700. 


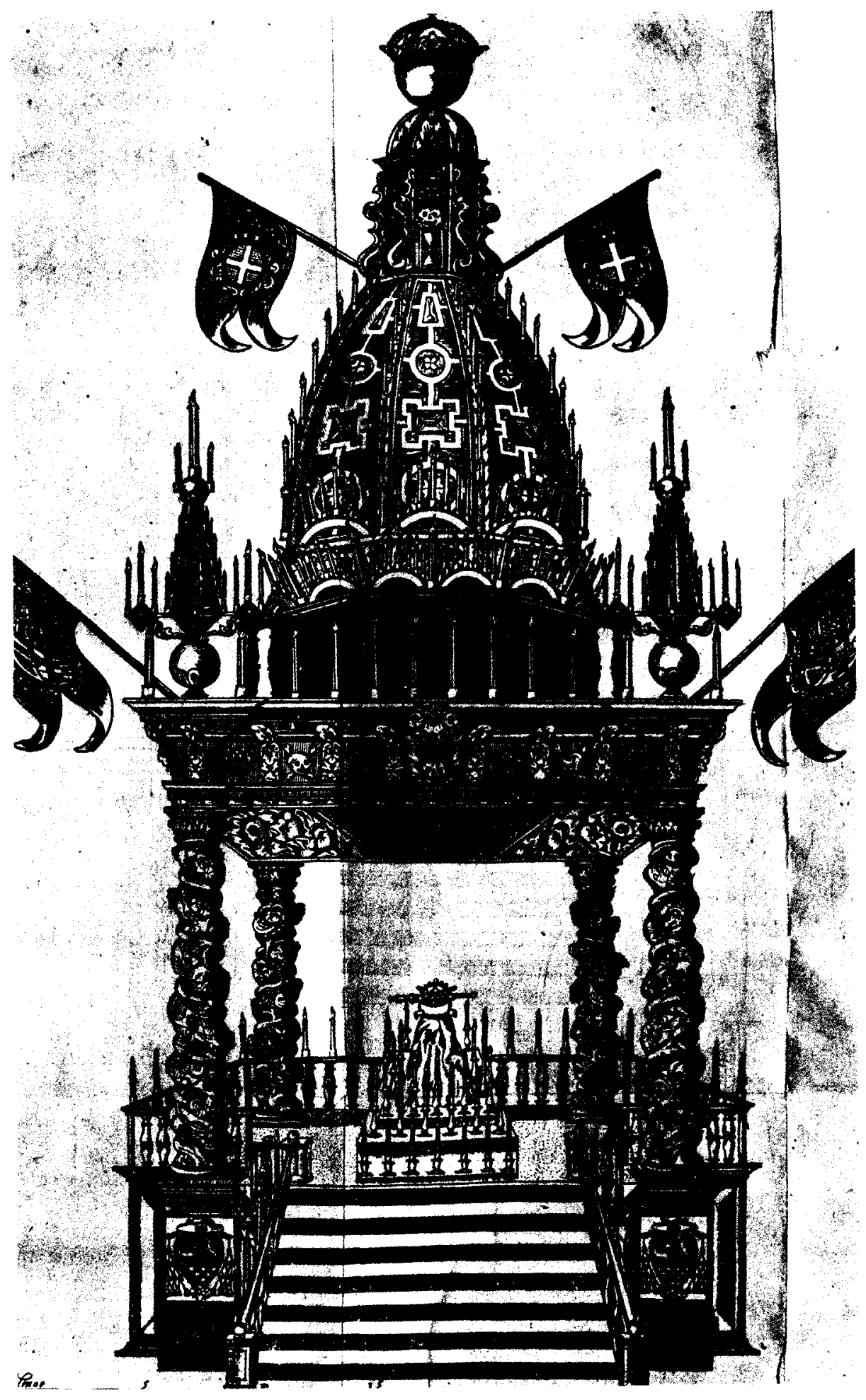

Fig. 2. Túmulo de las exequias celebradas de la Universidad de Zaragoza, el año de 1714, por la reina Maria Luisa Gabriela de Saboya, 


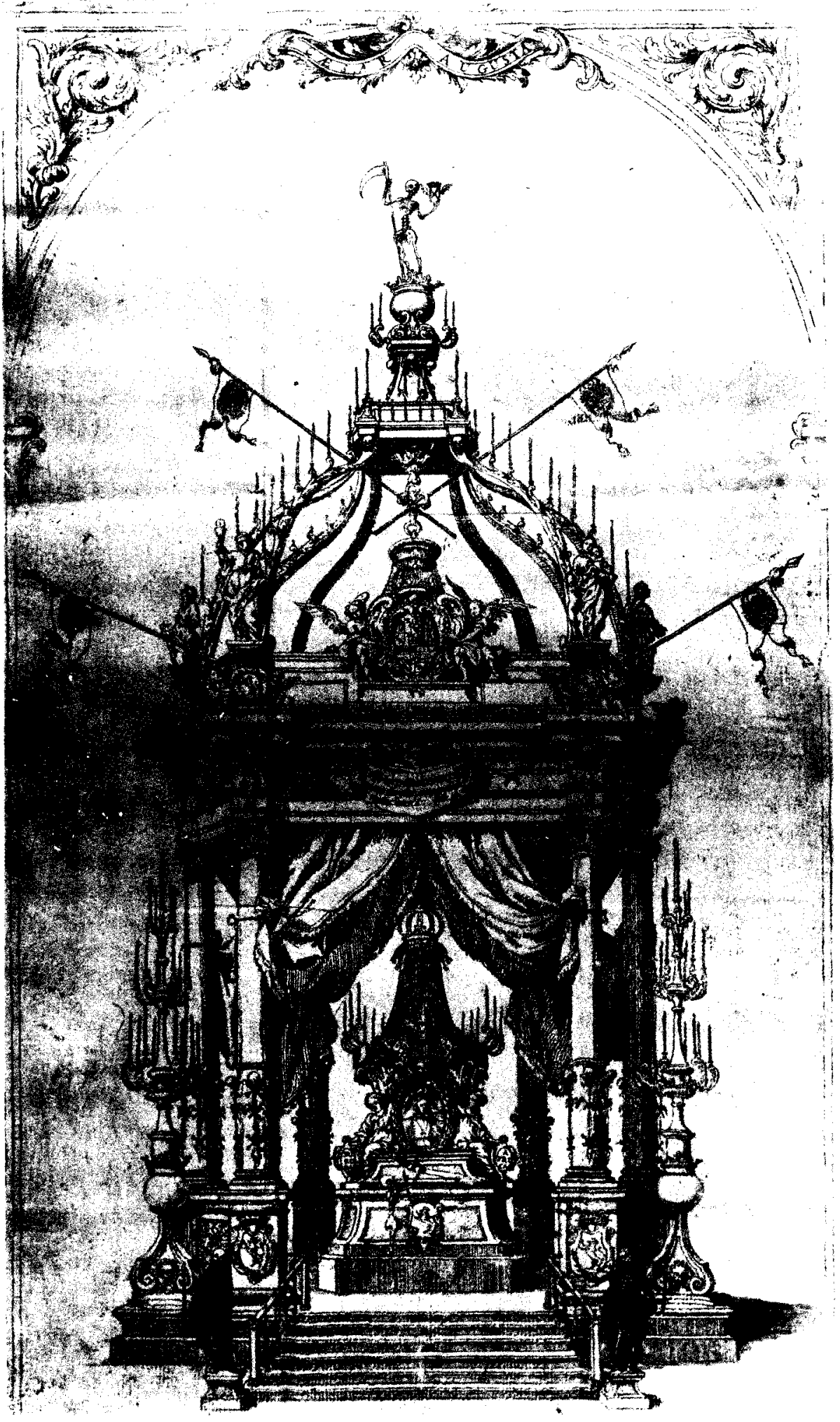

Fig. 3. Túmulo de las exequias que la ciudad de Zaragoza levantó por Carlos II (1700). 


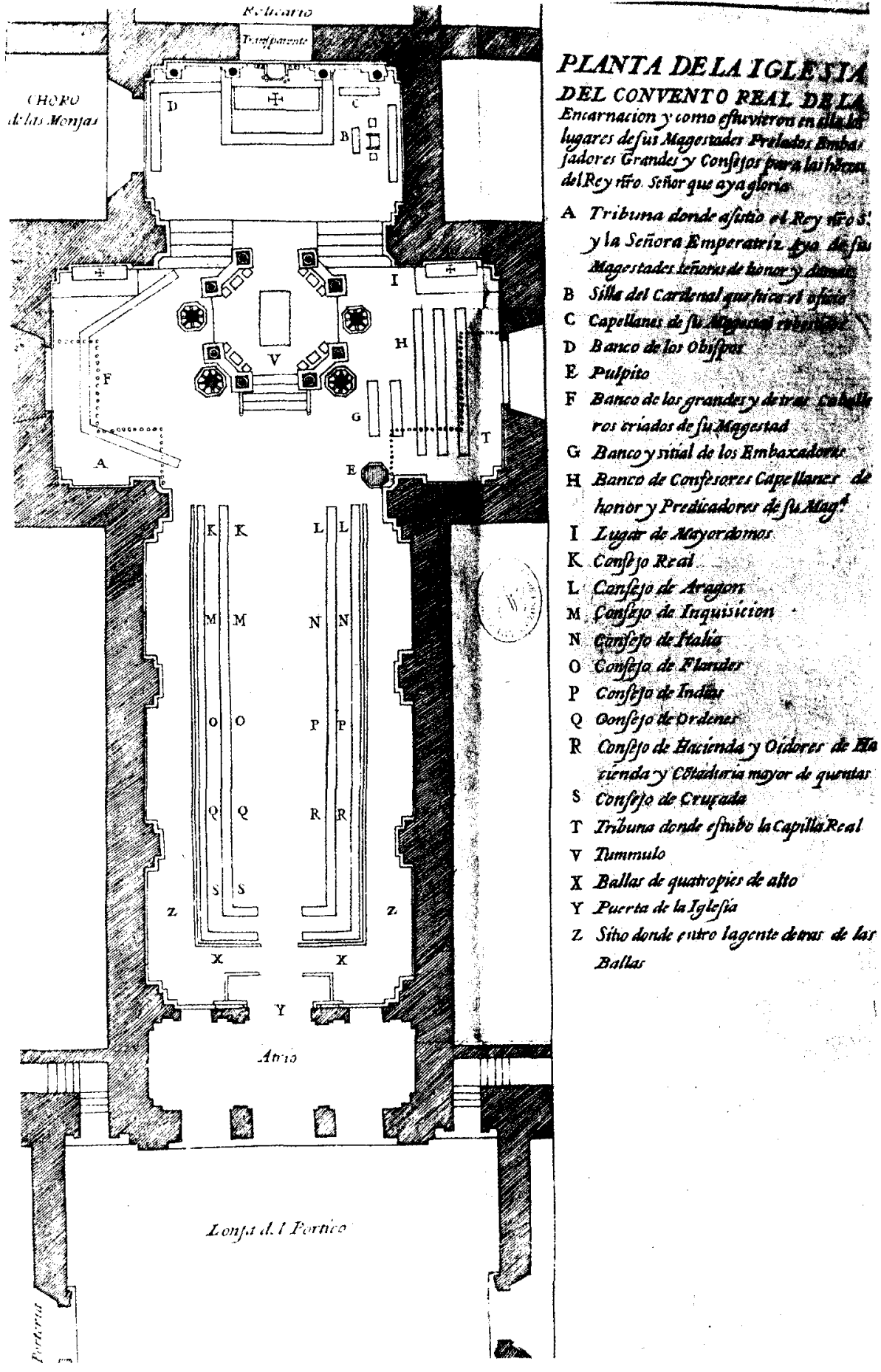

Fig. 4. Plano y distribución de las honras celebradas en el Real Convento de la Encarnación de Madrid por el rey Felipe IV (1666). 


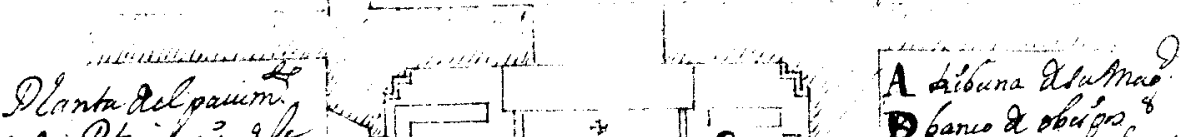
Cnevroum alas.

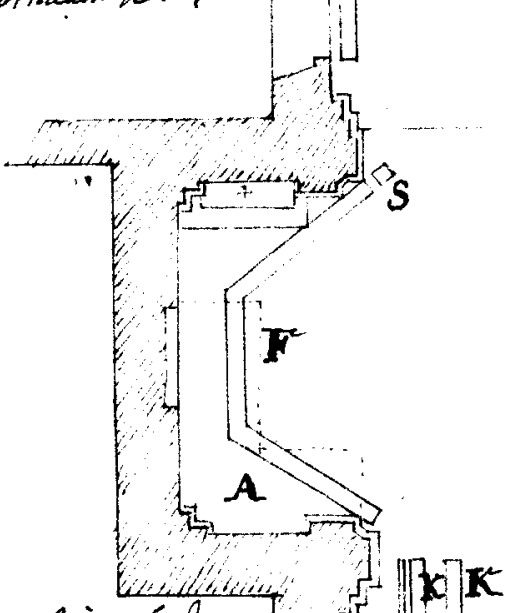

R.

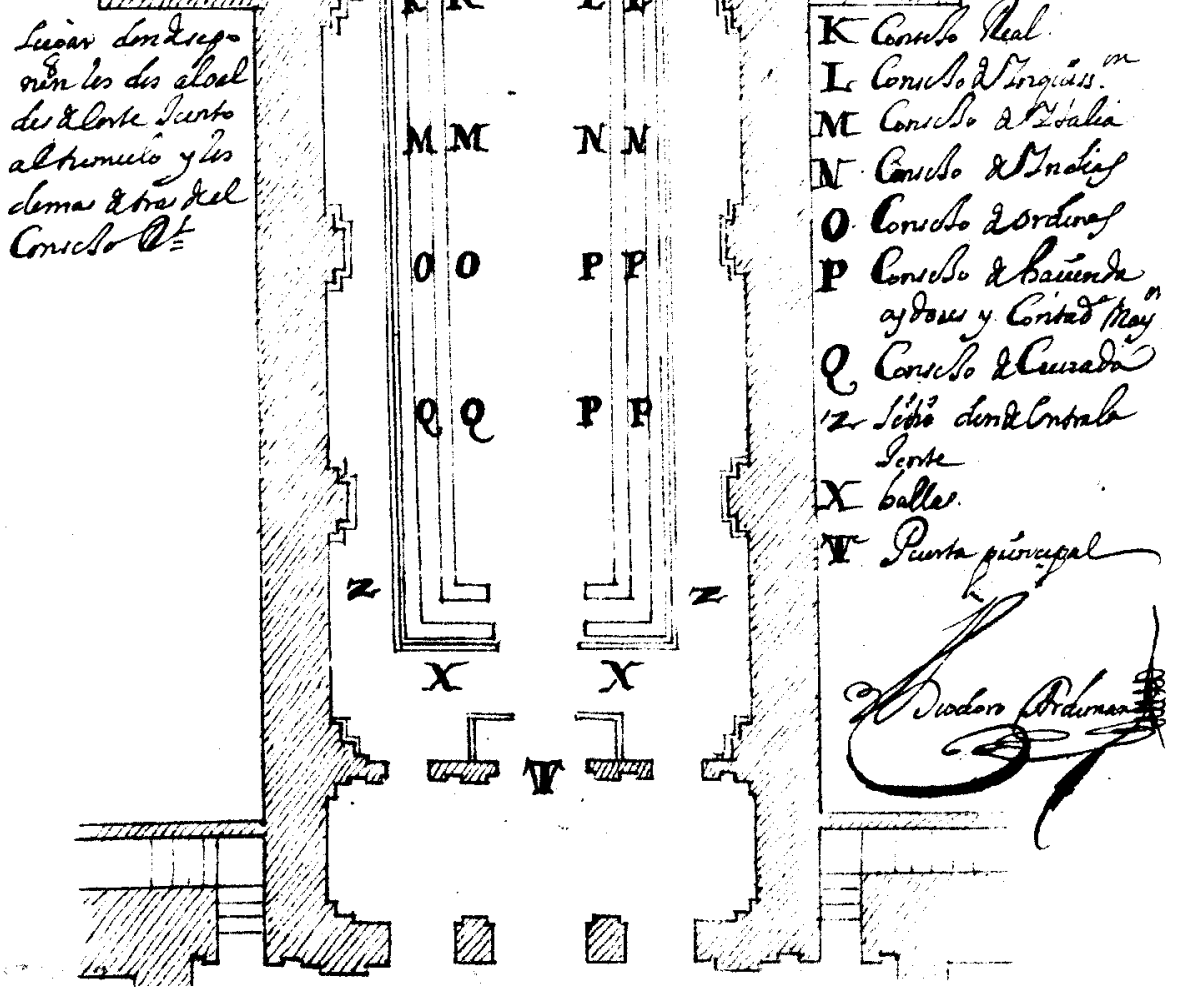

Fig. 5. Planta y distribución de la iglesia de la Encarnación de Madrid, realizado por Teodoro Ardemans con motivo de las exequias por el Delfin de Francia. 


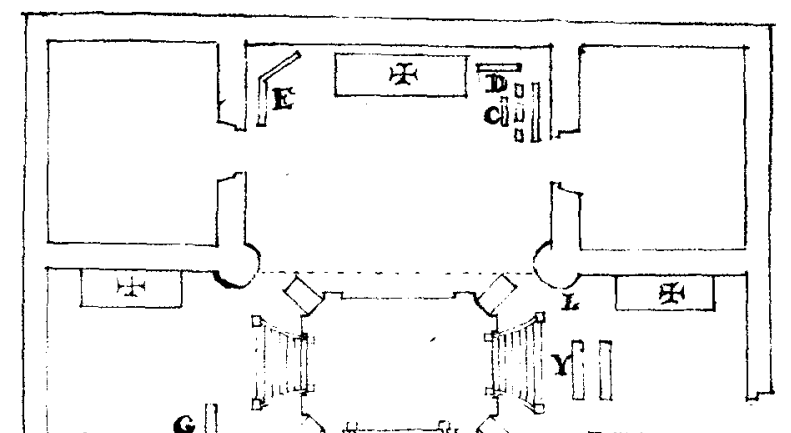

Plema scla Leria sewan Gommo De heline pana la

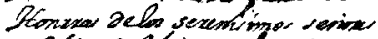
ocefin pel finie De fanria: que

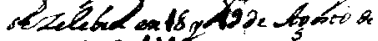
erte anio aldi:

A hibuene derw hingara:

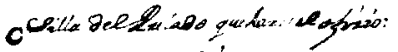

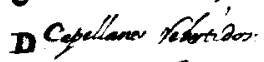

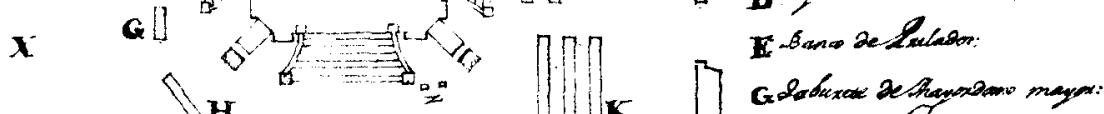
H-Sanco de Giana

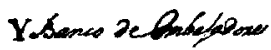

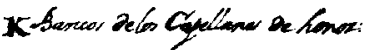
MConesos teal.

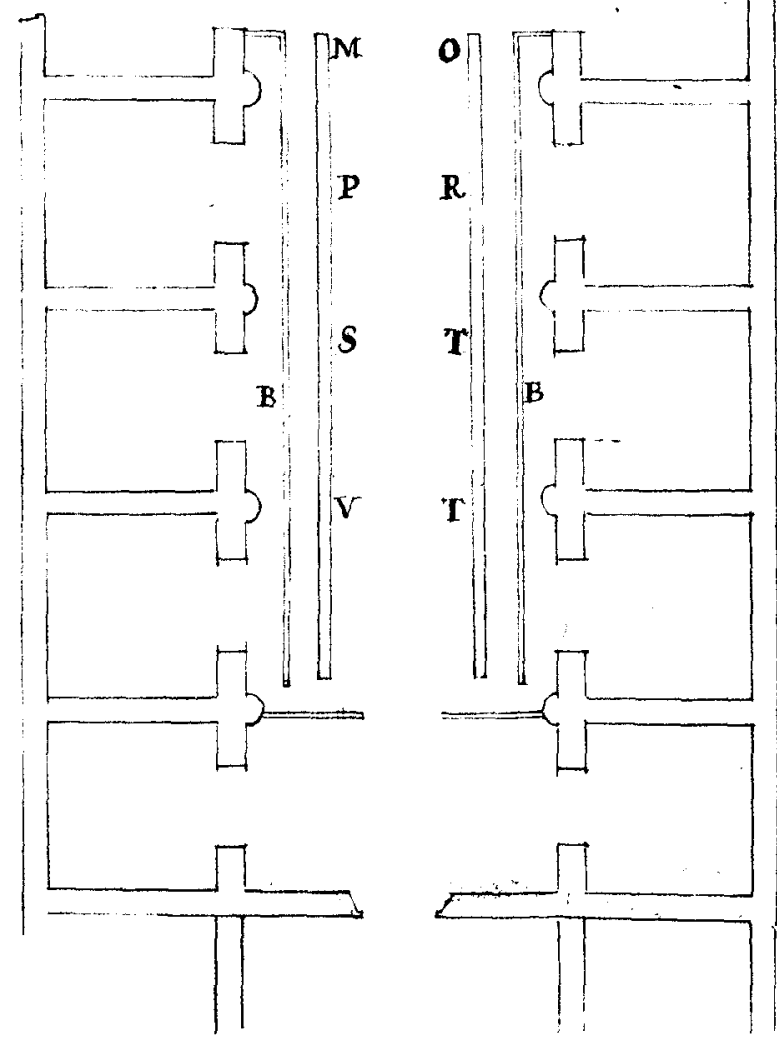

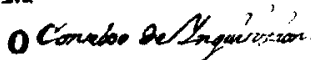
$\mathrm{p}$ Conveso ve Ptabí R. Comeso De Proner scinewe de oxpena:

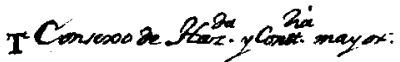
vCowas ae Crunear:

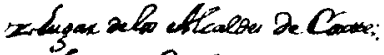

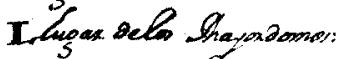

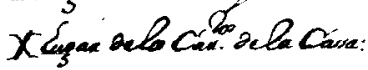
B.balles:

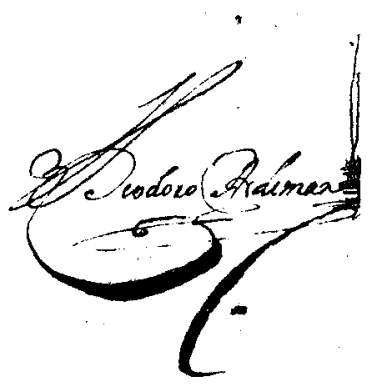

Fig. 6. Planta y distribución de la iglesia del convento de los Jerónimos para las exequias por los Delfines de Francia, celebradas en 1712. Dibujo realizado por Teodoro Ardemans. 


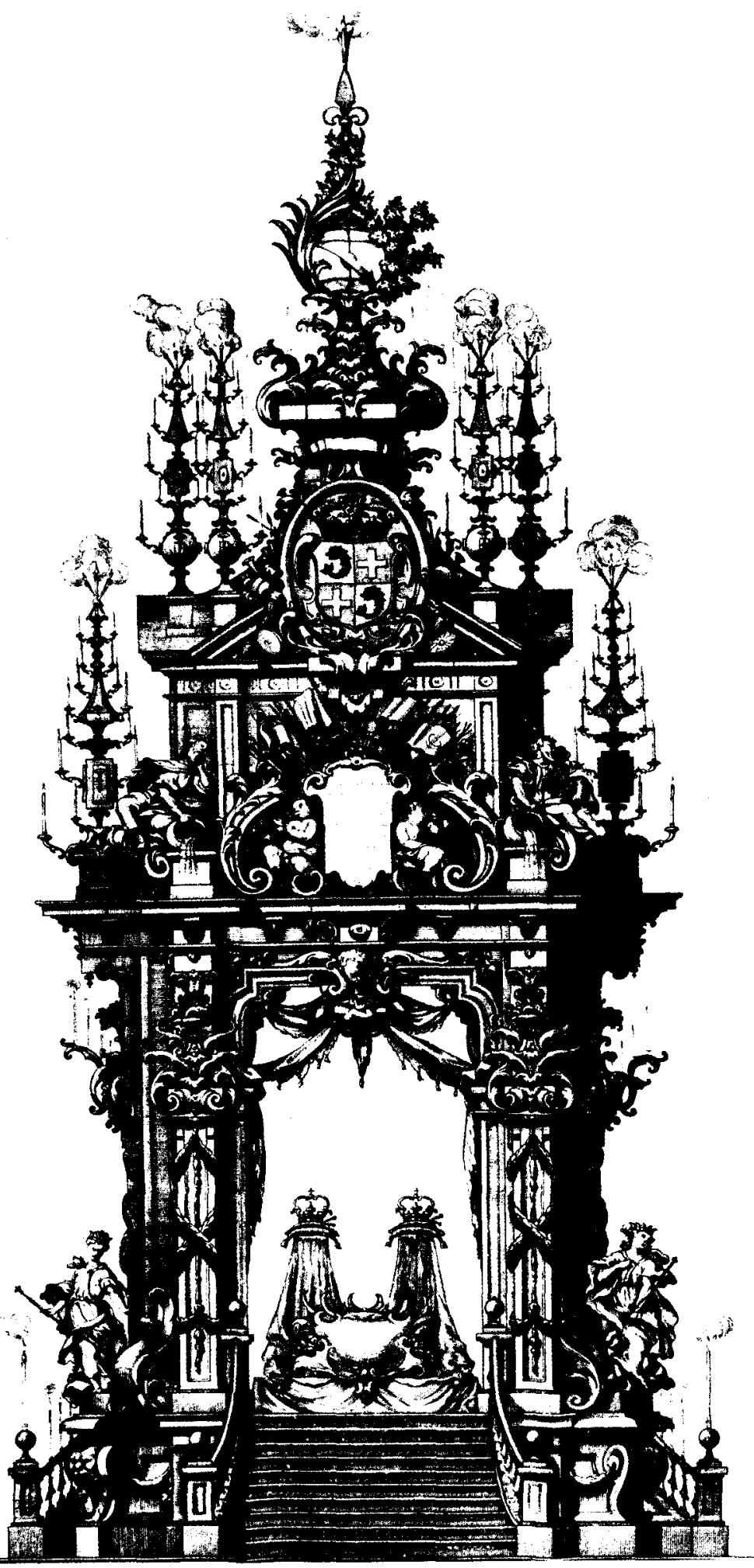

Fig. 7. Teodoro Ardemans, Arquitecto Mayor, fue el encargado de dirigir la construcción del túmulo para las exequias por Luis y Maria Adelaida. Delfines de Francia, en 1712. 


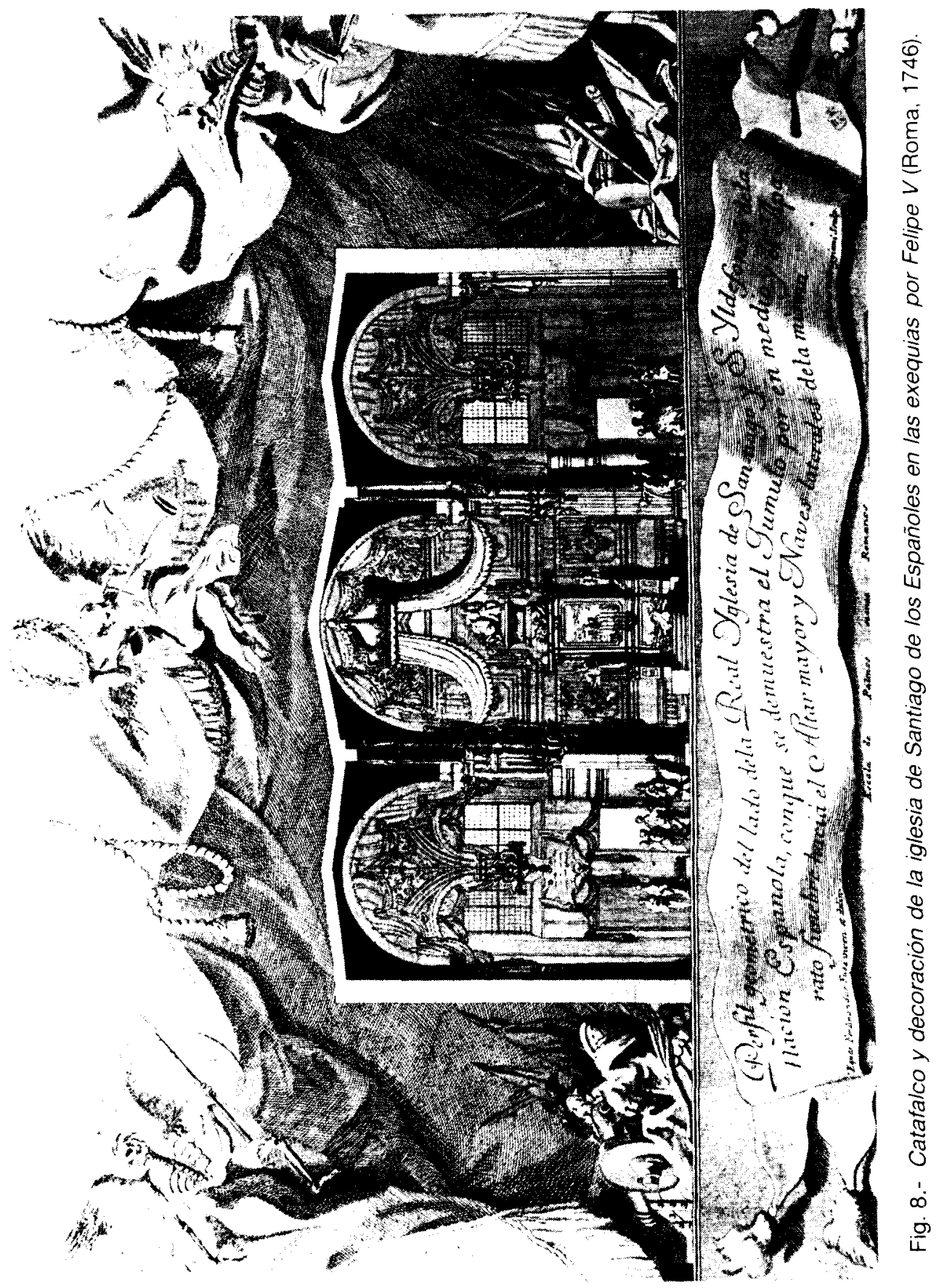




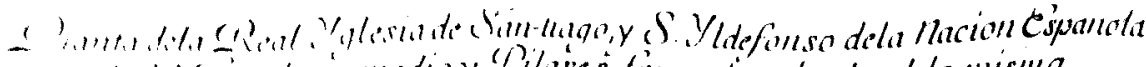

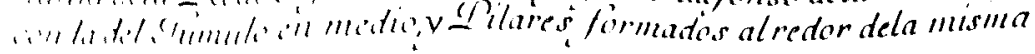
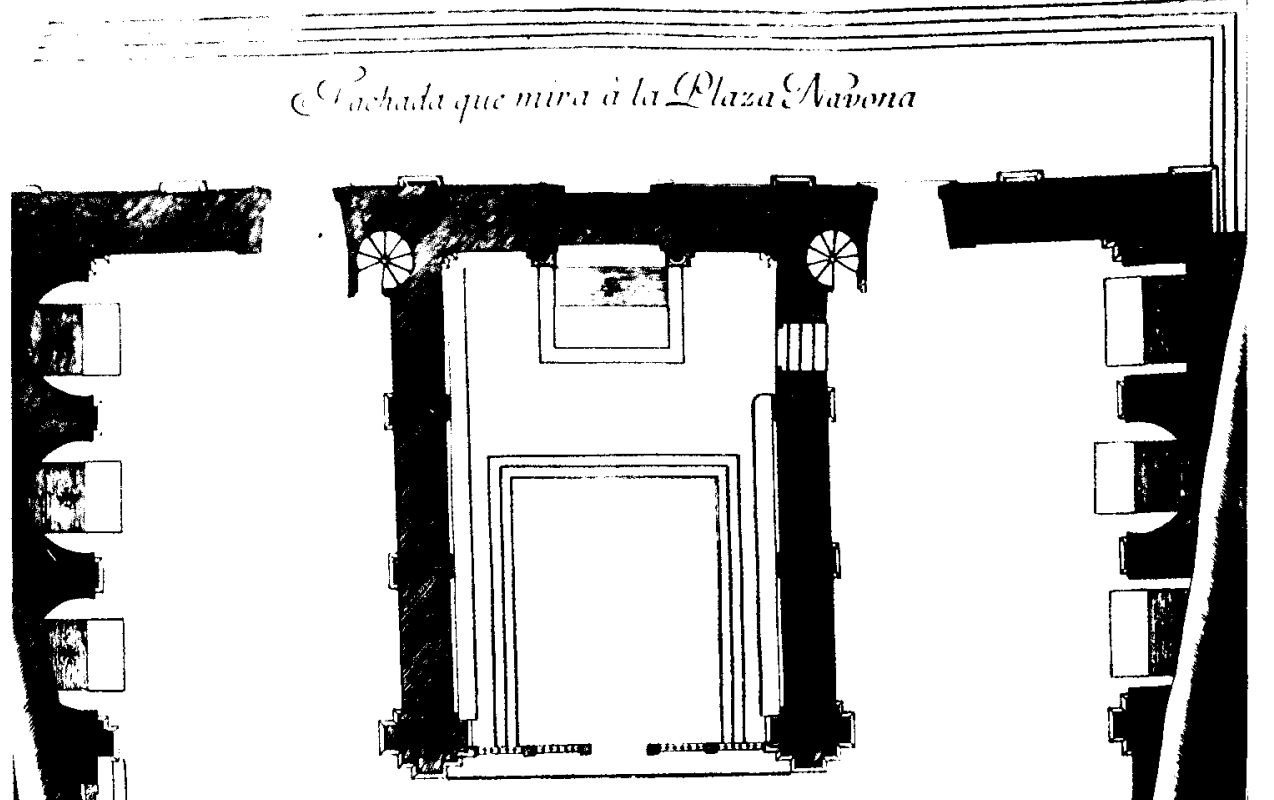


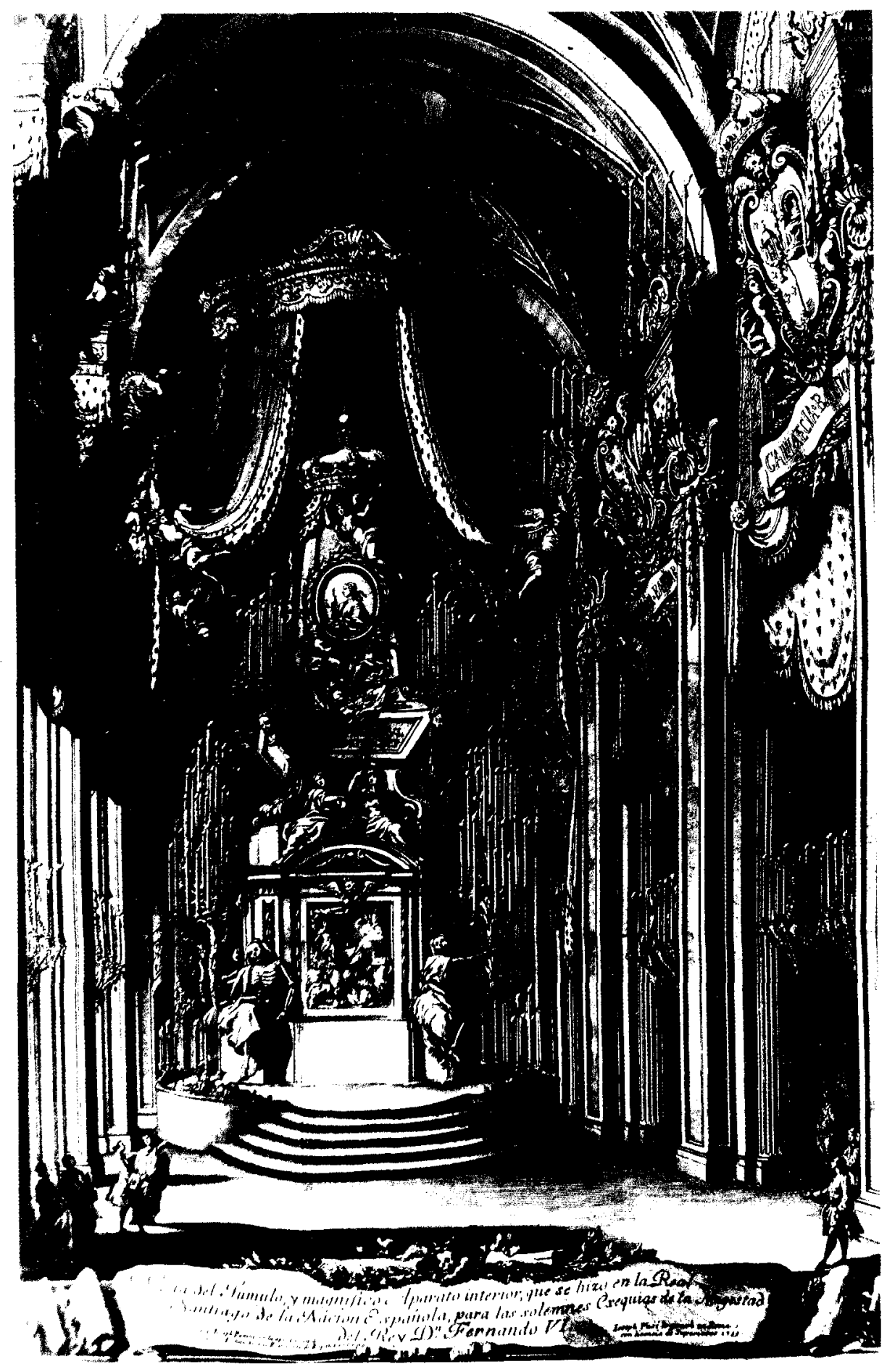

Fig. 10. Túmulo y decoración de la iglesia de Santiago de los Españoles de Roma en las exequias de Fernando VI, en 1759. 